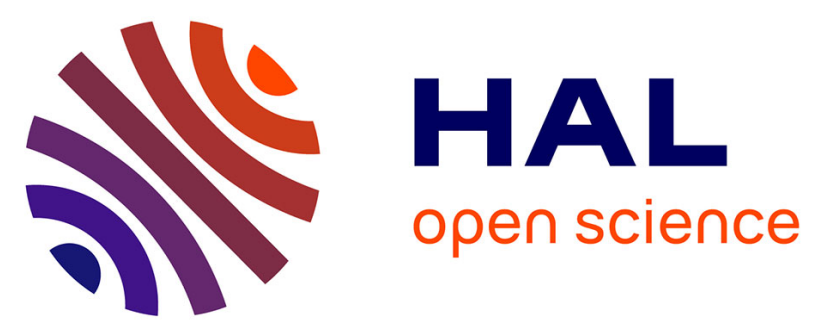

\title{
One-year metreleptin improves insulin secretion in patients with diabetes linked to genetic lipodystrophic syndromes
}

C. Vatier, S. Fetita, P. Boudou, C. Tchankou, L. Deville, Jp. Riveline, J. Young, L. Mathivon, F. Travert, D. Morin, et al.

\section{To cite this version:}

C. Vatier, S. Fetita, P. Boudou, C. Tchankou, L. Deville, et al.. One-year metreleptin improves insulin secretion in patients with diabetes linked to genetic lipodystrophic syndromes. Diabetes, Obesity and Metabolism, 2016, 10.1111/dom.12606 . hal-01259859

\section{HAL Id: hal-01259859 \\ https://hal.sorbonne-universite.fr/hal-01259859}

Submitted on 21 Jan 2016

HAL is a multi-disciplinary open access archive for the deposit and dissemination of scientific research documents, whether they are published or not. The documents may come from teaching and research institutions in France or abroad, or from public or private research centers.
L'archive ouverte pluridisciplinaire HAL, est destinée au dépôt et à la diffusion de documents scientifiques de niveau recherche, publiés ou non, émanant des établissements d'enseignement et de recherche français ou étrangers, des laboratoires publics ou privés. 
Short running title : Metreleptin effect on insulin secretion in lipodystrophic syndromes

C. Vatier ${ }^{1,2}$, S. Fetita ${ }^{3}$, P. Boudou ${ }^{4}$, C. Tchankou ${ }^{3}$, L. Deville ${ }^{5}$, JP. Riveline ${ }^{3,6}$, J. Young ${ }^{7}$, L. Mathivon ${ }^{8}$, F. Travert $^{9}$, D. Morin ${ }^{10}$, J. Cahen ${ }^{11}$, O. Lascols ${ }^{1,2,12}$, F. Andreelli ${ }^{2,13}$, Y. Reznik ${ }^{14}$, E. Mongeois ${ }^{15}$, I. Madelaine ${ }^{5}$, MC.

9 ' ${ }^{1}$ Sorbonne Universités, UPMC Univ Paris 06, and INSERM, UMR_S938, Centre de Recherche Saint-Antoine, F-75012, Paris, France

${ }^{2}$ ICAN, Institute of Cardiometabolism and Nutrition, F-75013, Paris, France

${ }^{3}$ AP-HP, Groupe Hospitalier Lariboisière-Saint-Louis, Service de Diabétologie et Endocrinologie, F-75010,

${ }^{4}$ AP-HP, Hôpital Saint-Louis, Service de Biochimie, F-75010, Paris, France

${ }^{5}$ AP-HP, Hôpital Saint-Louis, Département de Pharmacie, F-75010, Paris, France

${ }^{6}$ INSERM, UMR_S1138, Centre de Recherche des Cordeliers, Paris, F-75006 France

${ }^{7}$ AP-HP, Hôpital Bicêtre, Service d'Endocrinologie et des Maladies de la Reproduction, F-94275, Le Kremlin-

Bicêtre, France

${ }^{8}$ Centre Hospitalier de Meaux, Service de Pédiatrie, F-77104, Meaux, France

${ }^{9}$ AP-HP, Hôpital Bichat, Service d’Endocrinologie, Diabétologie, Nutrition F-75018, Paris, France

${ }^{10}$ CHRU Montpellier, Hôpital Arnaud de Villeneuve, Service de Pédiatrie, 34295 Montpellier, France

${ }^{11}$ Centre Hospitalier, Service d'Endocrinologie et Métabolismes, 95100 Argenteuil, France

${ }^{12}$ AP-HP, Hôpital Saint-Antoine, Laboratoire Commun de Biologie et Génétique Moléculaires, F-75012, Paris,

France

${ }^{13}$ AP-HP, Groupe Hospitalier Pitié-Salpêtrière, Service de Diabétologie, F-75013 Paris, France

${ }^{14}$ Service d'Endocrinologie, Centre Hospitalier Universitaire Côte-de-Nacre, F-14033, Caen, France; Equipe d'Accueil 2608, Université de Caen-Basse Normandie, F-14032, Caen, France; Unité sous Contrat 2006, Institut

28 National de la Recherche Agronomique, F-14032 Caen, France;

$29{ }^{15}$ Centre Hospitalier Régional d'Orléans, Service d'Endocrinologie, F-45000 Orléans, France

$30{ }^{16}$ Centre Hospitalier Régional Universitaire de Lille, Service d’Endocrinologie et Métabolisme, F-59037 Lille, 
31 France

$32 \quad{ }^{17}$ Université Paris-Diderot Paris-7, Paris, France

33

$34 *$ These authors contributed equally to this work

35

36

37 Corresponding authors:

38 Corinne Vigouroux, INSERM UMR_S938, Faculté de Médecine Pierre et Marie Curie, site Saint Antoine, 27

39 rue Chaligny, 75571, Paris Cedex 12, France.

40 Fax: +33 14001 14 32, Phone: +33 14001 14 84, corinne.vigouroux@inserm.fr

41

42 


\section{ABSTRACT}

44 Recombinant methionyl human leptin (metreleptin) therapy was shown to improve hyperglycemia, dyslipidemia 45 and insulin sensitivity in patients with lipodystrophic syndromes, but its effects on insulin secretion remain 46 controversial.

47 We used dynamic intravenous clamp procedures to measure insulin secretion, adjusted to insulin sensitivity, at baseline and after one-year metreleptin therapy, in 16 consecutive patients with lipodystrophy, diabetes and

49 leptin deficiency.

50 Patients, aged $39.2 \pm 4$ years (mean \pm SEM), presented with familial partial lipodystrophies $(\mathrm{n}=11,10$ women) 51 or congenital generalized lipodystrophy ( $\mathrm{n}=5,4$ women). Their BMI $\left(23.9 \pm 0.7 \mathrm{~kg} / \mathrm{m}^{2}\right), \mathrm{HbA1c}(8.5 \pm 0.4 \%)$ 52 and serum triglycerides $(4.6 \pm 0.9 \mathrm{mmol} / \mathrm{l})$ significantly decreased within 1 month of metreleptin therapy, then 53 remained stable. Insulin sensitivity (from hyperglycaemic or euglycemic hyperinsulinemic clamps, $n=4$ and 12 , 54 respectively), insulin secretion during graded glucose infusion $(n=12)$, and acute insulin response to intravenous 55 glucose adjusted to insulin sensitivity (disposition index, $n=12$ ), significantly increased after 1 year of 56 metreleptin therapy. Increase in disposition index was related to decrease in percent total and trunk body fat.

57 Metreleptin therapy improves not only insulin sensitivity, but also insulin secretion in patients with diabetes due 58 to genetic lipodystrophies. 
61 Leptin deficiency, linked to reduced fat amount, is thought to importantly contribute to the metabolic 62 complications associated with lipodystrophic syndromes, as shown by studies in mice [1,2] and humans [3,4]. In 63 generalized forms of lipodystrophies, metreleptin therapy dramatically decreased liver and muscle lipid content, 64 improving insulin sensitivity, hyperglycemia and dyslipidemia, partly independently of decreased caloric intake $65[3,4]$. However, in partial forms of lipodystrophies, the effect of metreleptin on hyperglycemia has not been 66 clearly established in patients with moderate baseline metabolic alterations [5-7]. In addition, the effect of metreleptin on insulin secretion, which remains controversial, has been previously investigated using only oral glucose tolerance tests $[3,6,8-10]$.

69 In this study, we evaluated the effect of metreleptin on insulin sensitivity and insulin secretion using dynamic 70 intravenous clamp procedures in 16 patients with genetic lipodystrophy syndromes, included in a compassionate 71 therapeutic programme.

\section{METHODS}

(see also Supplementary appendix)

\section{Patients}

Twenty-two non HIV-infected patients with genetic or acquired, partial or generalized lipodystrophy, diabetes and low serum leptin (ie, fasting leptin $\leq 6 \mathrm{ng} / \mathrm{ml}$ ), entered a compassionate programme of metreleptin therapy approved by the National French Health Agency. Among them, sixteen consecutive patients older than 16 years gave their informed consent for metabolic investigations at baseline and after one year of therapy, which were approved by the local ethics committee (Comité de Protection des Personnes, Paris-St-Louis). Pharmaceuticals, San Diego, CA), self-administered in one daily subcutaneous injection at the initial dose of $0.02 \mathrm{mg} / \mathrm{kg}$ (M0) increased to $0.08 \mathrm{mg} / \mathrm{kg}$ at one month (M1), was added to the patients' regimen, stable for at least 6 weeks. Every three months, metreleptin and other medications were adapted to tolerance and effectiveness, and anthropometric parameters, lipid profile, $\mathrm{HbA1c}$, renal and liver function tests were collected. The mean metreleptin daily dose at one year (M12) was $0.10 \mathrm{mg} / \mathrm{kg} \pm 0.02$ (SEM). 
The first four patients ( 1 to 4 ) were evaluated with hyperglycemic clamps, and the twelve subsequent patients (5 to 16) with euglycemic hyperinsulinemic clamps and intravenous glucose tolerance test (IVGTT) followed by a graded IV-glucose infusion (glucose ramping).

Hyperglycemic clamps allowed the measurement of acute insulin response to an intravenous bolus of glucose

94 (AIR), and the ratio of the glucose disposal rate to insulin concentration (M/I) at the $200 \mathrm{mg} / \mathrm{dl}$-hyperglycemic plateau, as an estimate of insulin sensitivity.

Euglycemic hyperinsulinemic clamps estimated the whole-body insulin sensitivity to glucose, expressed as the insulin-stimulated glucose disposal rate (M-value), further adjusted to insulin concentrations (M/I). AIR was calculated from IVGTT. Insulin secretion rates (ISR) in response to four-step graded glucose infusions evaluated the beta-cell sensitivity to glucose.

100 The disposition index was calculated as the product of AIR by M measured during euglycemic hyperinsulinemic clamps [11].

102

\section{Statistical analyses}

104 A favorable effect of metreleptin on glucose control was defined as a 0.5-point decrease in HbA1c, or HbA1c stability with a decrease of more than $50 \%$ in total daily insulin or oral antidiabetic doses, or discontinuation of one antidiabetic class, between M0 and M12. Results are presented as mean \pm SEM, unless otherwise specified. See File S1 for supplemental methods and references.

\section{RESULTS}

\section{Anthropometric and metabolic markers}

112 Patients with diabetes, attributable to familial partial lipodystrophy (FPLD) linked to LMNA (nine women),

113 PPARG (one man) or PLIN1 mutations (one woman), or to congenital generalized lipodystrophy attributable to 114 AGPAT2 mutations (CGL1) (four women, one man) were included in the study (Table S1). They presented 115 different forms of lipodystrophic syndromes with insulin resistance and dyslipidemia, attributable to already 116 described causative mutations (for review, see [12]). Their age and BMI were $39.2 \pm 4.0$ years and $23.9 \pm 0.7$ $117 \mathrm{~kg} / \mathrm{m}^{2}$, respectively. Their serum leptin was low $(2.7 \pm 0.5 \mathrm{ng} / \mathrm{ml})$, related to fat mass $\left(\mathrm{r}^{2}=0.7, \mathrm{p}=0.003\right)$. BMI, 118 total energy intake (but not food macronutrient distribution), HbAlc, triglycerides, aspartate aminotransferase 119 (AST) and gamma glutamyl transferase levels significantly decreased within the first month of metreleptin 
121 metreleptin therapy, proportion of total body fat and lean masses were not significantly modified, but abdominal

122 and percentage of truncal fat decreased or tended to decrease. Patients used a lower number of antidiabetic 123 classes, and three among nine of them stopped insulin therapy (Table 1). One-year changes in BMI, HbA1c and

124 triglycerides were not significantly related to baseline leptin levels.

125 Fourteen of 16 patients met the criteria for a glucose response to metreleptin. However, one of these fourteen 126 patients cannot be formally considered as a responder since, although her glucose control was strikingly 127 improved after one-year metreleptin whereas glitazones were stopped, her basal insulin doses were increased 128 from 24 to $30 \mathrm{U} /$ day and her metformin dose from $1 \mathrm{~g}$ to $3 \mathrm{~g}$ per day (patient 9, Table S2). The two non-responder 129 patients were the only patient with a PLINI-linked partial lipodystrophy, and a patient with FPLD2 with 130 moderately elevated baseline HbA1c (patients 6 and 12, Table S2). None of them reported any difficulties 131 regarding the compliance with the treatment. Compared to other patients with partial lipodystrophies, they had 132 baseline values of serum leptin, percent body fat, waist circumference and duration of diabetes above the median 133 levels. They were the only patients who did not lose, or even gained weight $(+0$ and $+3.2 \mathrm{~kg}$, respectively) over 134 the one-year period.

\section{Insulin sensitivity}

136 Insulin-stimulated glucose disposal rate during euglycaemic hyperinsulinemic clamp ( $\mathrm{n}=12)$ significantly 137 increased during metreleptin therapy, from $2.72 \pm 0.79$ to $5.44 \pm 1.19 \mathrm{mg} / \mathrm{kg}$ of fat free mass $/ \mathrm{min}$ (p=0.0005) for $138 \mathrm{M}$-value and $0.013 \pm 0.005$ to $0.031 \pm 0.008 \mathrm{mg} / \mathrm{kg}$ of fat free mass $/ \mathrm{min} / \mathrm{pmol} / \mathrm{l}$ for $\mathrm{M} / \mathrm{I}(\mathrm{p}=0.02)$, showing that 139 the whole-body insulin sensitivity improved. Of note, in three patients (patients 6, 8 and 13, Table S1), 140 euglycemia was maintained without any glucose infusion during the hyperinsulinemic clamp at baseline, while a 141 significant glucose infusion rate was mandatory after one year-metreleptin therapy, pointing to a significant 142 improvement in insulin sensitivity. In the four patients evaluated with the hyperglycemic clamp, M/I increased 143 by a mean of $48 \%$ (Table S3).

\section{Insulin secretion}

145 Acute insulin response to intravenous glucose (AIR, $n=16$ ) did not significantly increased after one-year 146 metreleptin therapy $(88.9 \pm 27.5 \mathrm{pmol} / \mathrm{kg} / \mathrm{min}$ at $\mathrm{M} 0$ and $128.8 \pm 36.4$ at $\mathrm{M} 12, \mathrm{p}=0.19)$. However, insulin 147 secretion rate (ISR) during glucose ramping was higher at every hyperglycemic step (ANOVA overall effect 
$\mathrm{p}<0.0001$ ), and the disposition index (AIR x M-value), which adjusts the acute beta-cell function to insulin

149 sensitivity [11] increased after one-year metreleptin ( $\mathrm{n}=12$ ) (Figure 1) (Table S3). The AIR x M/I index, assessed

150 in the whole group, also significantly increased (from $6.3 \pm 3.8$ to $9.2 \pm 3.1, \mathrm{p}=0.02$ ).

151 Although one-year changes in HbA1c, triglycerides, M-value, and AIR were not significantly associated with

152 modifications in anthropometric parameters (data not shown), disposition index variation was significantly

153 related to changes in percent total body fat $\left(r^{2}=0.71, p=0.008\right)$, and percent trunk fat mass $\left(r^{2}=0.40, p=0.05\right)$.

154

\section{Metreleptin response in the $L M N A$-mutated subgroup of patients}

156 In patients with $L M N A$ mutations (n=9), BMI, HbA1c, triglycerides and liver enzymes significantly decreased

157 after one-year metreleptin therapy (data not shown), while M-value increased from $2.88 \pm 1.13$ to $6.85 \pm 1.65$

$158 \mathrm{mg} / \mathrm{kg}$ of fat free mass $/ \mathrm{min}(\mathrm{n}=7, \mathrm{p}=0.02)$. ISR increased or tended to increase at the four steps of glucose

159 ramping, with a mean increase of $36 \%$, and the disposition index significantly increased, from $208.8 \pm 154.3$ to

$1601068 \pm 543.9(\mathrm{n}=7, \mathrm{p}=0.02)$ (Figure S2 and Table S3). In this group, the decrease of HbA1c at M12 was

161 positively correlated with the initial HbA1c level $\left(\mathrm{r}^{2}=0.7, \mathrm{p}=0.03\right)$, but was not related to the initial leptinemia.

162

\section{DISCUSSION}

164 In patients with lipodystrophy, metreleptin therapy was shown to improve insulin sensitivity [8,13,14]. However

165 the studies that investigated its effects on insulin secretion were done using oral glucose tolerance tests, and gave

166 heterogeneous results [3,6,8-10]. Interestingly, leptin has been shown to have dual effects on pancreatic beta-cell

167 function: while suppressing insulin gene expression and secretion, it also inhibits ectopic lipid storage in islet

168 cells, thus preventing lipotoxicity in rodent models [15].

169 The present study, which used dynamic i.v. clamp techniques in 16 patients with diabetes and endogenous

170 hypoleptinemia due to genetically-determined lipodystrophic syndromes, shows that metreleptin treatment for 1

171 year significantly improved insulin secretion. It also confirms that it decreased HbAlc, triglycerides and liver

172 enzymes and enhanced insulin sensitivity, with a two-fold increase in insulin-stimulated glucose disposal rate

173 after one year, as reported [8]. Importantly, in this context of severe insulin resistance, we adjusted insulin

174 secretion measurements for insulin sensitivity using the disposition index, based on the hyperbolic function

175 linking acute insulin response and insulin sensitivity [11]. Improvement of this index showed that, in patients

176 with lipodystrophy, metreleptin therapy increased beta-cell sensitivity to glucose. 
Metreleptin-induced changes in disposition index and body fat mass and distribution were correlated, suggesting

178 that improvement in beta-cell secretory function could result from decreased lipotoxicity. In accordance, the two

179 non-responder patients did not lose, or even gained weight under metreleptin. Leptin could also inhibit glucagon

180 oversecretion, which was reported in insulin-deficient mice [16] and remains to be investigated in patients with

181 lipodystrophy under metreleptin therapy.

182 In patients with partial forms of lipodystrophies as a result of mutations in the LMNA gene, defects of insulin 183 secretion have been suspected to prevent the beneficial effect of metreleptin on glucose homeostasis [5]. Our 184 present results show that metreleptin therapy also increases insulin secretion in this subgroup of patients, 185 affected by typical Dunnigan syndrome (FPLD2) [17] or by previously described mixed laminopathic 186 phenotypes associating lipodystrophic syndrome and progeroid or cardiomyopathic signs [18,19]. In addition, in 187 accordance with recent findings showing that, in patients with partial lipodystrophy, metreleptin was mainly 188 useful if metabolic derangements were severe [7], the present study shows that effect of metreleptin on glucose 189 control in these patients was related to the baseline level of HbA1c.

190 In conclusion, 1 year of metreleptin therapy improves beta-cell function in patients with lipodystrophy, leptin 191 deficiency and diabetes. Improved insulin secretion, related to fat mass and distribution changes, probably 192 contributes to the metabolic benefits of metreleptin. Further studies are required to investigate whether these 193 effects are maintained over time and to study mechanisms by which metreleptin affects the islets. Leptin has 194 been proposed to protect the islets by acting on several pathophysiological steps involved in beta-cell 195 lipotoxicity and in glucagon production during diabetes [20]. These leptin-regulated pathways, which control, 196 among others, de novo ceramide synthesis, could be further studied in response to metreleptin therapy.

\section{ACKNOWLEDGEMENTS}

200 We thank the patients who participated in this study, the nurses from the Diabetology-Endocrinology 201 Department of Saint-Louis hospital, Paris, France, David Savage of Addenbrooke's Hospital, Cambridge, UK for 202 help with a genetic diagnosis, Profs Eric de Kerviler of AP-HP, Department of Radiology, Saint-Louis Hospital, 203 Paris, France and Robert Carlier and Mr Dominique Laurent of AP-HP, Department of Radiology, Raymond204 Poincaré Hospital, Paris, France for CT-scan analyses, Amylin/Bristol-Myers Squibb/AstraZeneca and in 205 particular Dr Jean Chan and Ms Poonam Rohilla for generously providing metreleptin. 
This work was supported by funding sources from DHOS-INSERM (Translational clinical research 2010),

ICAN Foundation (grant ANR-10-IAHU) and the National Program for Diabetes Research (PNRD/ARD).

210 C.Vatier was the recipient of a PhD grant from the Conseil Régional d'Ile de France (Cardiovasculaire-Obésité-

211 Diabète Domaine d'Intérêt Majeur). C.T received grants from the Société Francophone du Diabète.

212 C. Vatier, JF. Gautier and C. Vigouroux designed the study, managed the metreleptin therapy, performed the 213 metabolic clamps, collected and analysed the data and wrote the manuscript. S. Fetita, C. Tchankou and JP. 214 Riveline performed the metabolic clamps. P. Boudou performed the biochemical tests. L. Deville and I. 215 Madelaine managed the metreleptin delivery. J. Young, L. Mathivon, F. Travert, D. Morin, J. Cahen, F. 216 Andreelli, Y. Reznik, E. Mongeois, MC. Vantyghem and C. Vigouroux referred the patients and collected data. O. Lascols performed the genetic analyses. All authors approved the final version of the manuscript.

\section{SUPPORTING INFORMATION}

Additional Supporting Information may be found in the online version of this article :

221 File S1. Supplemental methods and references.

222 Figure S1. Longitudinal effects of metreleptin therapy in the 16 patients.

223 Figure S2. Effects of metreleptin on insulin secretion in patients with LMNA mutations.

224 Table S1. Baseline characteristics of the 16 studied patients.

225 Table S2. Use of antidiabetic medications during metreleptin therapy.

226 Table S3. Insulin secretion and insulin sensitivity indexes before and one year after metreleptin therapy.

\section{REFERENCES}

1. Shimomura I, Hammer RE, Ikemoto S, Brown MS, Goldstein JL. Leptin reverses insulin resistance and diabetes mellitus in mice with congenital lipodystrophy. Nature 1999; 401: 73-76.

2. Colombo C, Cutson JJ, Yamauchi T et al. Transplantation of adipose tissue lacking leptin is unable to reverse the metabolic abnormalities associated with lipoatrophy. Diabetes 2002; 51: 2727-2733.

3. Javor ED, Cochran EK, Musso C, Young JR, Depaoli AM, Gorden P. Long-term efficacy of leptin replacement in patients with generalized lipodystrophy. Diabetes 2005; 54: 1994-2002.

4. Chong AY, Lupsa BC, Cochran EK, Gorden P. Efficacy of leptin therapy in the different forms of human lipodystrophy. Diabetologia 2010; 53: 27-35. replacement therapy in moderately and severely hypoleptinemic patients with familial partial lipodystrophy of 
6. Park JY, Javor ED, Cochran EK, DePaoli AM, Gorden P. Long-term efficacy of leptin replacement in patients with Dunnigan-type familial partial lipodystrophy. Metabolism 2007; 56: 508-516.

7. Diker-Cohen T, Cochran E, Gorden P, Brown RJ. Partial and generalized lipodystrophy: comparison of baseline characteristics and response to metreleptin. J Clin Endocrinol Metab 2015; 100: 1802-1810.

8. Ebihara K, Kusakabe T, Hirata M et al. Efficacy and safety of leptin-replacement therapy and possible mechanisms of leptin actions in patients with generalized lipodystrophy. J Clin Endocrinol Metab 2007; 92: 532541.

9. Guettier JM, Park JY, Cochran EK et al. Leptin therapy for partial lipodystrophy linked to a PPARgamma mutation. Clin Endocrinol (Oxf) 2008; 68: 547-554.

10. Muniyappa R, Brown RJ, Mari A et al. Effects of Leptin Replacement Therapy on Pancreatic beta-Cell Function in Patients With Lipodystrophy. Diabetes Care 2014; 37: 1101-1107.

11. Kahn SE, Prigeon RL, McCulloch DK et al. Quantification of the relationship between insulin sensitivity and beta-cell function in human subjects. Evidence for a hyperbolic function. Diabetes 1993; 42: 1663-1672.

12. Vatier C, Bidault G, Briand $\mathrm{N}$ et al. What the genetics of lipodystrophy can teach us about insulin resistance and diabetes. Curr Diab Rep 2013; 13: 757-767.

13. Oral EA, Simha V, Ruiz E et al. Leptin-replacement therapy for lipodystrophy. N Engl J Med 2002; 346: 570-578.

14. Beltrand J, Beregszaszi M, Chevenne D et al. Metabolic correction induced by leptin replacement treatment in young children with Berardinelli-Seip congenital lipoatrophy. Pediatrics 2007; 120: e291-e296.

15. Lee YH, Magkos F, Mantzoros CS, Kang ES. Effects of leptin and adiponectin on pancreatic beta-cell function. Metabolism 2011; 60: 1664-1672.

16. Yu X, Park BH, Wang MY, Wang ZV, Unger RH. Making insulin-deficient type 1 diabetic rodents thrive without insulin. Proc Natl Acad Sci U S A 2008; 105: 14070-14075.

17. Vigouroux C, Magré J, Vantyghem MC et al. Lamin A/C gene: sex-determined expression of mutations in Dunnigan-type familial partial lipodystrophy and absence of coding mutations in congenital and acquired generalized lipoatrophy. Diabetes 2000; 49 : 1958-1962.

18. Caron M, Auclair M, Donadille B et al. Human lipodystrophies linked to mutations in A-type lamins and to HIV protease inhibitor therapy are both associated with prelamin A accumulation, oxidative stress and premature cellular senescence. Cell Death Differ 2007; 14: 1759-1767.

19. Garg A, Speckman RA, Bowcock AM. Multisystem dystrophy syndrome due to novel missense mutations in the amino-terminal head and alpha-helical rod domains of the lamin A/C gene. Am J Med 2002; 112: 549-55.

20. Unger RH, Roth MG. A new biology of diabetes revealed by leptin. Cell Metab 2015; 21: 15-20. 


\section{FIGURE 1 LEGEND}

\section{Effect of metreleptin therapy on insulin secretion}

A. Insulin secretion rates (ISR) during graded glucose infusion were calculated for each of the four glucose infusion steps (of 4, 8, 10 and $12 \mathrm{mg} / \mathrm{kg}$ of body weight of glucose per min) and plotted against the corresponding mean glucose concentration, in patients 5 to 16 . Mean values obtained at baseline are represented as empty circles, and those obtained at one year-metreleptin therapy as filled triangles. Whiskers represent SEM.

${ }^{*} \mathrm{p}<0.05$ versus $\mathrm{M} 0$

B. Disposition index, indicating the insulin secretion capacity relative to insulin sensitivity, was calculated in the same patients as the product of $\mathrm{M}$ value measured during the euglycemic hyperinsulinemic clamp by AIR. Rectangles represent $25^{\text {th }}$ and $75^{\text {th }}$ percentile values, with the median values depicted in-between. Whiskers represent the lowest datum still within 1.5 IQR of the lower quartile, and the highest datum still within 1.5 IQR of the upper quartile (Tukey boxplot).

M0: baseline, M12: after 12 months of metreleptin therapy; ${ }^{*} \mathrm{p}<0.05$ versus $\mathrm{M} 0$ 
Table 1: Metabolic markers at baseline and after one year of metreleptin treatment in the sixteen studied patients

\begin{tabular}{lllll}
\hline Variable & Baseline & 12 month-metreleptin & $\mathbf{p}$ \\
\hline
\end{tabular}

\section{Body weight and body composition}

BMI $\left(\mathrm{kg} / \mathrm{m}^{2}\right)$

Waist circumference $(\mathrm{cm})$

Abdominal total adipose tissue area $\left(\mathrm{cm}^{2}\right.$, CT-scan)

Abdominal visceral adipose tissue area $\left(\mathrm{cm}^{2}, \mathrm{CT}\right.$-scan $)$

Abdominal subcutaneous adipose tissue area $\left(\mathrm{cm}^{2}\right.$, CT-scan)

Fat mass (\% of total body mass, DEXA)

Trunk fat mass ( $\%$ of total body mass, DEXA)

Lean mass ( $\%$ of total body mass, DEXA)

\section{$\underline{\text { Energy intake }}$}

Total food intake (Kcal/day)

Metabolic, renal and liver parameters

Systolic blood pressure $(\mathrm{mmHg})$

HbA1c (\%)

Fasting Glucose (mmol/l)

Fasting Insulin (pmol/l)

LDL-cholesterol (mmol/l)

HDL-cholesterol (mmol/l)

Triglycerides $(\mathrm{mmol} / \mathrm{l})$

Aspartate aminotransferase (AST) (IU/l)

Alanine aminotransferase (ALT) (IU/l)

Gamma glutamyl transferase (GGT) (IU/l)

Creatinine $(\mu \mathrm{mol} / \mathrm{l})$

Albumin excretion rate $(\mathrm{mg} / \mathrm{l})$

\section{Therapy}

Antidiabetic medication classes per patient

Insulin users (n)

Lipid-lowering medications per patient

$23.9(0.7)$
$81.8(7.0)$

$195.9(29.3)$

$122.2(17.7)$

$73.7(13.6)$

$15.4(1.6)$

$18.7(2.4)$

$82.1(1.7)$

$1970(108.1)$

$$
\begin{gathered}
130.1(3.4) \\
8.5(0.4) \\
7.5(0.5)
\end{gathered}
$$

$259.2(81.2)$

$2.5(0.3)$

0.7 (0.04)

$4.6(0.9)$

$47.8(8.5)$

$70.9(17.2)$

$84.9(21.7)$

$62.4(4.8)$

$297.5(166.5)$

$2.2(0.28)$

$9 / 16$

Fibrate $9 / 16$

Statin $6 / 16$
$22.6(0.8)$

$77.5(8.5)$

1717 (112.8)

0.03

0.003

0.004

0.03

0.0005

0.006

0.6

0.08

0.8

85.5 (2.5)

$125.1(3.0)$

0.23

$7.5(0.3)$

0.005

$7.0(0.8)$

0.5

380.9 (125.8)

0.7

0.14

0.24

0.03

0.03

0.3

0.05

0.03

0.12

83.4 (55.9)

$1.6(0.26)$

0.008

$6 / 16$

Fibrate 9/16

Statin 4/16

Values are expressed as mean (SEM). $\mathrm{p}$ values are depicted in bold when considered significant $(\mathrm{p}<0.05)$.

Total, visceral and subcutaneous abdominal adipose tissue areas were evaluated form $1 \mathrm{~cm}$-reconstructed CT-scan slices at the L4 level. DEXA: dual energy x-ray absorptiometry 
Figure 1: Effect of metreleptin therapy on insulin secretion

A. Insulin secretion rates during graded glucose infusion

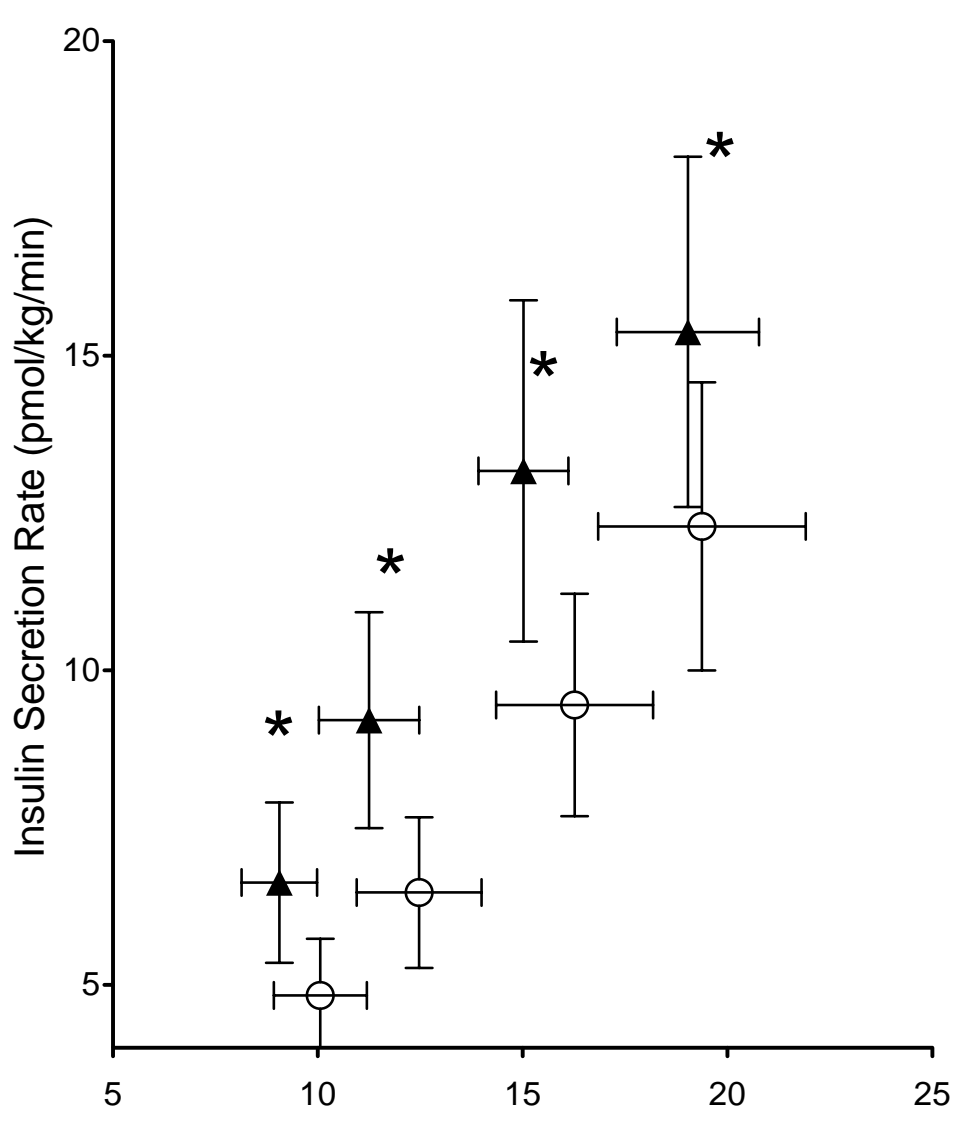

Glycemia $(\mathrm{mmol} / \mathrm{l})$
B. Integrative marker: disposition index

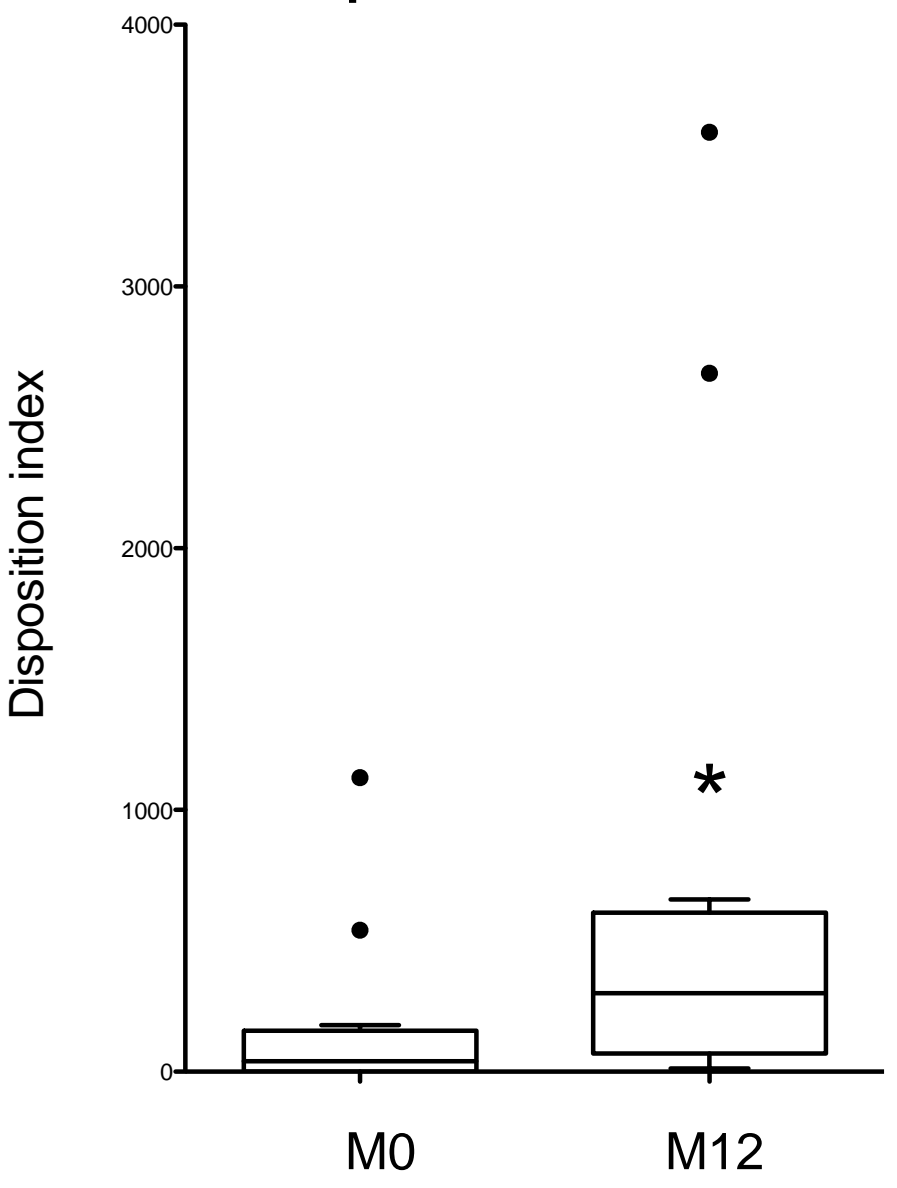

A After one-year metreleptin therapy (M12)

Baseline (M0) 


\section{Additional Supporting Information}

File S1. Supplemental methods and references

\section{Methods}

\section{Biochemical analyses}

HbA1c was measured using high performance liquid chromatography and plasma insulin using a immunoradiometric assay (BI-INSULIN IRMA, Cis Bio-International, Gif-Sur-Yvette, France).

The values of LDL-cholesterol were determined from total cholesterol, triglycerides and HDL-cholesterol levels using the Friedewald formula (LDL-cholesterol = total cholesterol minus HDL-cholesterol minus triglycerides (mg/dl) /5), when triglycerides levels were below $400 \mathrm{mg} / \mathrm{dl}$ ( $\mathrm{n}=9$ patients).

\section{Evaluation of body composition}

Total fat and lean masses, and body fat segmental distribution, were measured by dual energy x-ray absorptiometry (DEXA), and abdominal subcutaneous and visceral adipose tissue surfaces (SAT and VAT) were calculated from $1 \mathrm{~cm}$-reconstructed CT-scan slices at the L4 level as previously described [1].

Caloric and macronutrient intakes were evaluated by three-day food records performed at M0 and M12.

\section{Metabolic investigations}

Metabolic investigations were performed after a 12h-overnight fast at M0 and M12. When fasting glycemia was above $7 \mathrm{mmol} / \mathrm{l}$, a $2 \mathrm{~h}$-insulin infusion was performed before the investigations. Intravenous glucose tolerance tests (IVGTT, $n=16)$, hyperglycemic and euglycemic hyperinsulinemic clamps $(n=4$ and 12, respectively), and graded glucose infusion tests (glucose ramping, $\mathrm{n}=12$ ) were performed as previously described [2-6].

\section{Acute insulin response to an intravenous bolus of glucose (AIR) (n=16 patients)}

In all patients, a solution of $20 \%$ glucose of [weight $(\mathrm{kg}) \times(200-$ fasting glycemia $(\mathrm{mg} / \mathrm{dl})) \times 1.5$ ] / $200 \mathrm{ml} \mathrm{was}$ given within 30 seconds intravenously and measurements of plasma glucose and insulin were performed at $-5,0$, 2, 4, 6, 8 and $10 \mathrm{~min}$. AIR was defined as the incremental area under the curve of plasma insulin concentration above baseline between 2 and 10 min after intravenous glucose administration according to the trapezoid method. Baseline insulin (InsB) was the mean insulin level between -5 and $0 \mathrm{~min}\left[\left(\mathrm{Ins}_{-5 \mathrm{~min}}+\mathrm{Ins}_{0 \mathrm{~min}}\right) / 2\right]$. AIR= 
$[($ IT0min + IT2min $) / 2-$ IT0min $]+[($ IT2min + IT4min $) / 2-$ IT0min $]+[($ IT4min + IT6min $) / 2-$ IT0min $]+$

$[($ IT6min +

IT8min $) / 2-$ IT0min $]+[($ IT8min + IT10min $) / 2-$ IT0min $]$ and expressed as $\mathrm{pmol} / \mathrm{kg} / \mathrm{min}$.

\section{Hyperglycemic clamp (patients 1 to 4)}

Following the intravenous bolus of glucose for the AIR determination, we maintained plasma glucose at $200 \mathrm{mg} / \mathrm{dl}$ for $180 \mathrm{~min}$ by infusing $20 \%$ glucose at varying rates according to blood glucose measurements reformed at 5 min-intervals. Blood samples were collected at $160^{\text {th }}, 170^{\text {th }}$ and $180^{\text {th }}$ min for the measurement of plasma insulin and $\mathrm{C}$ peptide concentrations. We calculated the glucose disposal rate from the glucose infusion rate during the last $20 \mathrm{~min}$ of the hyperglycemic plateau after accounting for inter-individual differences in glucose space [3] (in mg/kg body fat-free mass/min). Glucose space correction was calculated as $\left(\mathrm{G}_{2}-\mathrm{G}_{1}\right) \times 0.095$ with $G_{2}$ and $G_{1}$ being the glucose concentrations in $\mathrm{mg} / \mathrm{dl}$ at the end and at the beginning of each 5-min period during the last $20 \mathrm{~min}$ of the clamp. The ratio of the glucose disposal rate to insulin concentration at the 200 $\mathrm{mg} / \mathrm{dl}$-hyperglycemic plateau (M/I) was used as an estimate of insulin sensitivity.

\section{Euglycemic hyperinsulinemic clamp (patients 5 to 16)}

The insulin-stimulated glucose disposal rate (M-value) was measured during a 100 min-step of 80 $\mathrm{mU} / \mathrm{m}^{2} / \mathrm{min}$ insulin infusion, while blood glucose was clamped at $100 \mathrm{mg} / \mathrm{dl}$ using variable infusion of $20 \%$ glucose. Blood samples were collected before the clamp and every $10 \mathrm{~min}$ during the last $20 \mathrm{~min}$, for the measurement of plasma glucose and insulin. The M-value was calculated according to DeFronzo et al. [3], after accounting for inter-individual differences in glucose space, and was expressed in $\mathrm{mg} / \mathrm{kg}$ of fat-free mass $/ \mathrm{min}$, using the formula described above. We also calculated the M/I ratio, which adjusted the M-value to the mean insulin concentration during the last 20 min of the test.

\section{Glucose ramping (graded glucose infusion test) (patients 5 to 16)}

This test consisted of four consecutive 40-min intravenous infusion of $4,8,10$ and $12 \mathrm{mg} / \mathrm{kg} / \mathrm{min}$ of glucose as previously described [2,4]. Blood samples were collected every 10 minutes during the whole procedure (200 $\mathrm{min})$. The insulin secretion rates (ISR), which evaluate the beta-cell sensitivity to glucose, were assessed from the changes in C-peptide concentrations and the pre-hepatic insulin secretion rate for each of the four glucose infusion steps. ISR was derived by deconvolution, assuming a two-compartmental model of Cpeptide clearance kinetic, using the ISEC software version 3.4a designed by Hovorka R et al (see [5] for more details). Mean ISR for each glucose infusion step was adjusted to fat-free mass and plotted against the 
corresponding mean glucose concentration, thereby establishing a dose-response relationship between plasma glucose and insulin secretion rate for each patient.

The disposition index (patients 5 to 16) was calculated as the product of AIR by M-value measured during euglycemic hyperinsulinemic clamps [6].

\section{Statistical analyses}

Statistical analyses were performed using GraphPad PRISM (GraphPad Software, Inc, CA, USA) and Statview (SAS Institute Inc., CA, Austria) statistical softwares. We used the Fisher exact test to compare categorical variables and the non-parametric Mann Whitney U test. Analysis of variance (ANOVA) and Wilcoxon rank-sum test for quantitative variables were performed for comparisons over time. The relationship between ISR and glucose levels during glucose ramp was analyzed using mixed model analysis of covariance. Correlations of different measures of glucose metabolism with body composition or age were evaluated using Spearman's rank correlation test or linear regression analysis. $P$ values $<0.05$ were considered significant.

\section{References}

1. Boufassa F, Goujard C, Viard JP et al. Immune deficiency could be an early risk factor for altered insulin sensitivity in antiretroviral-naive HIV-1-infected patients: the ANRS COPANA cohort. Antivir Ther 2012; 17: 91-100.

2. Gautier JF, Wilson C, Weyer C et al. Low acute insulin secretory responses in adult offspring of people with early onset type 2 diabetes. Diabetes 2001; 50: 1828-1833.

3. DeFronzo RA, Tobin JD, Andres R. Glucose clamp technique: a method for quantifying insulin secretion and resistance. Am J Physiol 1979; 237: E214-E223.

4. Sobngwi E, Boudou P, Mauvais-Jarvis F et al. Effect of a diabetic environment in utero on predisposition to type 2 diabetes. Lancet 2003; 361: 1861-1865.

5. Hovorka R, Soons PA, Young MA. ISEC: a program to calculate insulin secretion. Comput Methods Programs Biomed 1996; 50: 253-264.

6. Kahn SE, Prigeon RL, McCulloch DK et al. Quantification of the relationship between insulin sensitivity and beta-cell function in human subjects. Evidence for a hyperbolic function. Diabetes 1993; 42: $1663-1672$. 
Table S1: Baseline characteristics of the sixteen studied patients

\begin{tabular}{|c|c|c|c|c|c|c|c|}
\hline Patients & $\begin{array}{c}\text { Age } \\
\text { (years) }\end{array}$ & $\begin{array}{c}\text { Sex } \\
(\mathbf{M} / \mathbf{F})\end{array}$ & $\begin{array}{c}\text { Disease } \\
\text { (gene mutation) }\end{array}$ & $\underset{\left(\mathbf{k g} / \mathbf{m}^{2}\right)}{\mathbf{B M I}}$ & $\begin{array}{c}\text { Total body fat } \\
\text { mass }(\%, \text { DEXA })\end{array}$ & $\begin{array}{l}\text { Serum leptin } \\
(\mathrm{ng} / \mathrm{ml})\end{array}$ & $\begin{array}{c}\text { Known duration of } \\
\text { diabetes (years) }\end{array}$ \\
\hline 1 & 60 & $\mathrm{~F}$ & $\begin{array}{c}\text { FPLD2 } \\
\text { (HTZ } L M N A \text { p.R482W) }\end{array}$ & 22.8 & 21.8 & 0.6 & 23 \\
\hline 2 & 37 & $\mathrm{~F}$ & $\begin{array}{c}\text { FPLD2 } \\
\text { (HTZ LMNA p.R482W) }\end{array}$ & 25.7 & 18.1 & 1.4 & 16 \\
\hline 3 & 24 & $\mathrm{~F}$ & $\begin{array}{c}\text { CGL1 } \\
\text { (HMZ AGPAT2 p.L165- } \\
\text { Q196del) }\end{array}$ & 26.8 & 8.8 & 0.1 & 6 \\
\hline 4 & 17 & $\mathrm{~F}$ & $\begin{array}{c}\text { CGL1 } \\
\text { (HMZ AGPAT2 } \\
\text { p.Q196fsX228) }\end{array}$ & 20.3 & 11.2 & 1.7 & 3 \\
\hline 5 & 52 & $\mathrm{~F}$ & $\begin{array}{c}\text { CGL1 } \\
(\mathrm{HMZ} A G P A T 2 \text { p.K216X) }\end{array}$ & 21.5 & 8.4 & 0.1 & 38 \\
\hline 6 & 51 & $\mathrm{~F}$ & $\begin{array}{c}\text { FPLD4 } \\
\text { (HTZ PLIN1 } \\
\text { p.V398GfsX166) }\end{array}$ & 26.0 & 22.2 & 5.0 & 30 \\
\hline 7 & 50 & $\mathrm{~F}$ & $\begin{array}{c}\text { FPLD2 } \\
\text { (HTZ } L M N A \text { p.R482W) }\end{array}$ & 24.5 & 21.3 & 4.1 & 6 \\
\hline 8 & 41 & $\mathrm{~F}$ & $\begin{array}{c}\text { FPLD2 } \\
\text { (HTZ LMNA p.R482W) }\end{array}$ & 23.0 & 13.4 & 3.4 & 22 \\
\hline 9 & 19 & $\mathrm{~F}$ & $\begin{array}{c}\text { FPLD2 } \\
\text { (HTZ LMNA p.R482W) }\end{array}$ & 25.0 & 22.6 & 5.6 & 3 \\
\hline 10 & 50 & $\mathrm{~F}$ & $\begin{array}{c}\text { FPLD2 } \\
\text { (HTZ LMNA p.R482W) }\end{array}$ & 25.2 & 13.8 & 3.6 & 1 \\
\hline 11 & 16 & $\mathrm{~F}$ & $\begin{array}{l}\text { Progeroid laminopathy } \\
\text { (HTZ LMNA p.D47Y) }\end{array}$ & 17.4 & 7.2 & 1.1 & 2 \\
\hline 12 & 36 & $\mathrm{~F}$ & $\begin{array}{c}\text { FPLD2 } \\
\text { (HTZ LMNA p.R482W) }\end{array}$ & 24.5 & 24.2 & 3.9 & 22 \\
\hline 13 & 45 & M & $\begin{array}{c}\text { FPLD3 } \\
\text { (HTZ PPARG p.L339X) }\end{array}$ & 29.0 & 22.6 & 4.0 & 22 \\
\hline 14 & 29 & $\mathrm{~F}$ & $\begin{array}{c}\text { CGL1 } \\
\text { (HMZ AGPAT2 } \\
\text { p.Q196fsX228) }\end{array}$ & 24.1 & 10.1 & 2.2 & 29 \\
\hline 15 & 70 & M & $\begin{array}{c}\text { CGL1 } \\
(\mathrm{HMZ} A G P A T 2 \text { p.E172K) }\end{array}$ & 21.4 & 4.2 & 0.34 & 42 \\
\hline 16 & 31 & $\mathrm{~F}$ & $\begin{array}{l}\text { Mixed laminopathy } \\
\text { (HTZ LMNA p.R28W) }\end{array}$ & 24.8 & 16.9 & 6 & 20 \\
\hline Mean \pm SEM & $39.2 \pm 4.0$ & & & $23.9 \pm 0.7$ & $15.4 \pm 1.6$ & $2.7 \pm 0.5$ & $17.8 \pm 3.3$ \\
\hline
\end{tabular}

FPLD: Familial Partial Lipodystrophy; CGL: Congenital Generalized Lipoatrophy; AGL: Acquired Generalized Lipoatrophy; HTZ: heterozygous; HMZ: homozygous; DEXA: dual energy x-ray absorptiometry 
Table S2: Use of antidiabetic medications during metreleptin therapy

\begin{tabular}{|c|c|c|c|c|c|c|c|}
\hline \multirow{2}{*}{ Patients } & \multirow{2}{*}{$\begin{array}{c}\text { Type of } \\
\text { lipodystrophy }\end{array}$} & \multicolumn{2}{|c|}{ Antidiabetic treatment (except insulin) } & \multicolumn{2}{|c|}{ Insulin doses $(\mathrm{U} / \mathrm{d})$} & \multicolumn{2}{|c|}{ HbA1c } \\
\hline & & M0 & M12 & M0 & M12 & Mo & M12 \\
\hline 1 & FPLD2 & $\begin{array}{c}\text { Metformin } 3 \mathrm{~g} / \mathrm{d} \\
\text { Pioglitazone } 45 \mathrm{mg} / \mathrm{d} \\
\text { Glimepiride } 4 \mathrm{mg} / \mathrm{d}\end{array}$ & $\begin{array}{c}\text { Metformin } 3 \mathrm{~g} / \mathrm{d} \\
\text { Glimepiride } 4 \mathrm{mg} / \mathrm{d}\end{array}$ & 0 & 0 & 7.7 & 6.9 \\
\hline 2 & FPLD2 & $\begin{array}{l}\text { Metformin } 1.7 \mathrm{~g} / \mathrm{d} \\
\text { Pioglitazone } 30 \mathrm{mg} / \mathrm{d} \\
\text { Glibenclamide } 2 \mathrm{mg} / \mathrm{d}\end{array}$ & $\begin{array}{c}\text { Metformin } 1.7 \mathrm{~g} / \mathrm{d} \\
\text { Glibenclamide } 1 \mathrm{mg} / \mathrm{d}\end{array}$ & 0 & 0 & 7.7 & 6.9 \\
\hline 3 & CGL1 & Metformin 3g/d & Metformin $3 \mathrm{~g} / \mathrm{d}$ & 0 & 0 & 8.7 & 6 \\
\hline 4 & CGL1 & None & None & 61 & 0 & 7.6 & 6.4 \\
\hline 5 & CGL1 & None & None & 60 & 0 & 8.1 & 7.1 \\
\hline 6 & FPLD4 & Metformin $3 \mathrm{~g} / \mathrm{d}$ & Metformin $3 \mathrm{~g} / \mathrm{d}$ & 254 & 564 & 9 & 10.2 \\
\hline 7 & FPLD2 & Metformin $2 \mathrm{~g} / \mathrm{d}$ & Metformin $2 \mathrm{~g} / \mathrm{d}$ & 0 & 0 & 8.5 & 7.4 \\
\hline 8 & FPLD2 & Metformin $3 \mathrm{~g} / \mathrm{d}$ & Metformin $3 \mathrm{~g} / \mathrm{d}$ & 140 & 40 & 6.9 & 6.9 \\
\hline 9 & FPLD2 & $\begin{array}{c}\text { Metformin } 1 \mathrm{~g} / \mathrm{d} \\
\text { Pioglitazone } 45 \mathrm{mg} / \mathrm{d} \\
\text { Gliclazide } 120 \mathrm{mg} / \mathrm{d} \\
\text { Liraglutide } 1.8 \mathrm{mg} / \mathrm{d}\end{array}$ & $\begin{array}{c}\text { Metformin } 3 \mathrm{~g} / \mathrm{d} \\
\text { Gliclazide } 120 \mathrm{mg} / \mathrm{d} \\
\text { Liraglutide } 1.8 \mathrm{mg} / \mathrm{d}\end{array}$ & 24 & 30 & 12.1 & 9.2 \\
\hline 10 & FPLD2 & Metformin $1.7 \mathrm{~g} / \mathrm{d}$ & Metformin $1.7 \mathrm{~g} / \mathrm{d}$ & 0 & 0 & 7.1 & 6.2 \\
\hline 11 & $\begin{array}{l}\text { Progeroid } \\
\text { laminopathy }\end{array}$ & $\begin{array}{l}\text { Metformin } 1.4 \mathrm{~g} / \mathrm{d} \\
\text { Pioglitazone } 30 \mathrm{mg} / \mathrm{d}\end{array}$ & Metformin $1.4 \mathrm{~g} / \mathrm{d}$ & 202 & 0 & 10.4 & 9 \\
\hline 12 & FPLD2 & $\begin{array}{c}\text { Metformin } 0.7 \mathrm{~g} / \mathrm{d} \\
\text { Vildagliptin } 100 \mathrm{mg} / \mathrm{d}\end{array}$ & $\begin{array}{l}\text { Metformin } 0.7 \mathrm{~g} / \mathrm{d} \\
\text { Vildagliptin } 100 \mathrm{mg} / \mathrm{d}\end{array}$ & 0 & 0 & 7.1 & 7.2 \\
\hline 13 & FPLD3 & $\begin{array}{l}\text { Metformin } 3 \mathrm{~g} / \mathrm{d} \\
\text { Glibenclamide } 4 \mathrm{mg} / \mathrm{d} \\
\text { Liraglutide } 1.8 \mathrm{mg} / \mathrm{d}\end{array}$ & $\begin{array}{l}\text { Metformin } 3 \mathrm{~g} / \mathrm{d} \\
\text { Glibenclamide } 4 \mathrm{mg} / \mathrm{d} \\
\text { Liraglutide } 1.8 \mathrm{mg} / \mathrm{d}\end{array}$ & 0 & 0 & 10.8 & 9.9 \\
\hline 14 & CGL1 & Metformin $2.55 \mathrm{~g} / \mathrm{d}$ & None & 80 & 68 & 8.7 & 8 \\
\hline 15 & CGL1 & Metformin $3 \mathrm{~g} / \mathrm{d}$ & None & 180 & 180 & 8.3 & 6.8 \\
\hline 16 & $\begin{array}{c}\text { Mixed } \\
\text { laminopathy }\end{array}$ & $\begin{array}{c}\text { Metformin } 3 \mathrm{~g} / \mathrm{d} \\
\text { Glibenclamide } 4 \mathrm{mg} / \mathrm{d}\end{array}$ & Metformin $2.1 \mathrm{~g} / \mathrm{d}$ & 272 & 220 & 7.6 & 6 \\
\hline
\end{tabular}


Figure S1 : Longitudinal effects of metreleptin therapy in the 16 patients
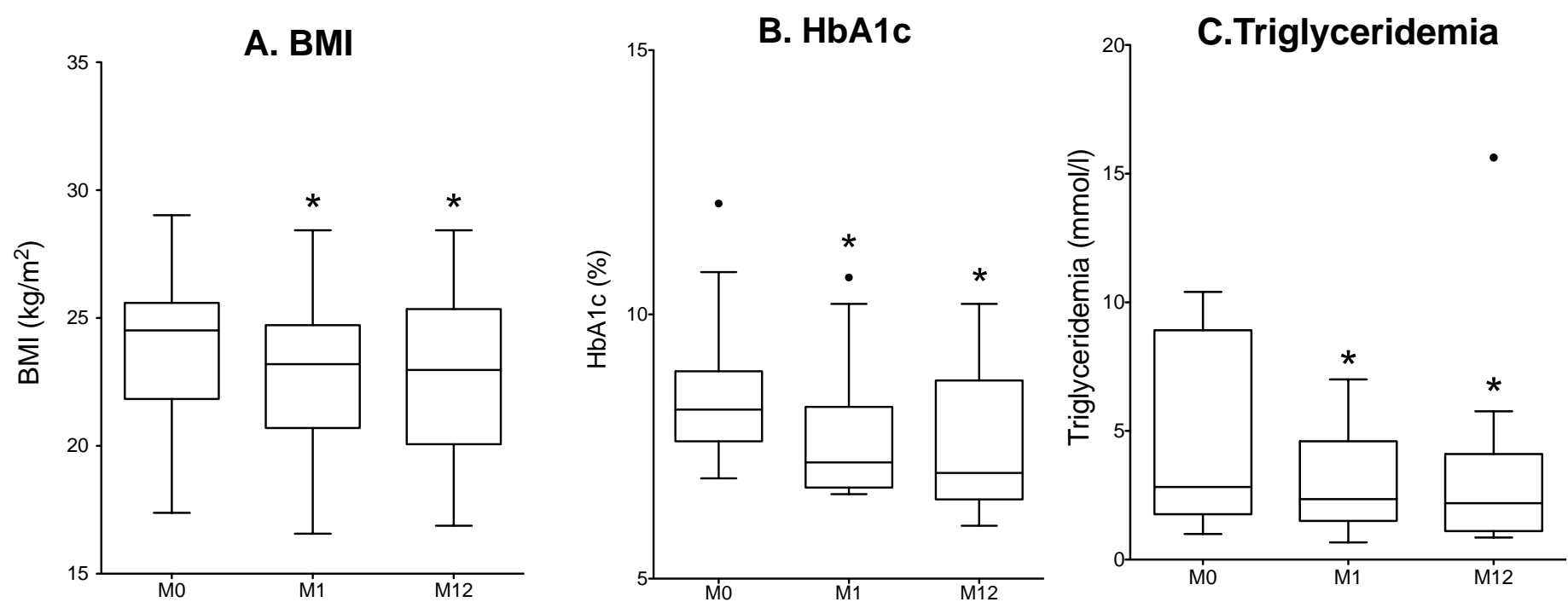

D.

\begin{tabular}{|c|c|c|c|c|c|c|}
\hline Variable & Baseline & $\begin{array}{c}1 \text { month- } \\
\text { metreleptin } \\
\text { therapy (M1) }\end{array}$ & $\begin{array}{l}\text { p M1 versus } \\
\text { baseline }\end{array}$ & $\begin{array}{l}12 \text { month- } \\
\text { metreleptin } \\
\text { therapy (M12) }\end{array}$ & $\begin{array}{l}\text { p M12 versus } \\
\text { baseline }\end{array}$ & $\begin{array}{c}\text { p M1 versus } \\
\text { M12 }\end{array}$ \\
\hline BMI $\left(\mathrm{kg} / \mathrm{m}^{2}\right)$ & $23.9(0.7)$ & $22.9(0.7)$ & 0.0009 & $22.6(0.8)$ & 0.003 & 0.06 \\
\hline HbA1c (\%) & $8.5(0.4)$ & $7.6(0.3)$ & 0.0005 & $7.5(0.3)$ & 0.005 & 0.57 \\
\hline $\begin{array}{l}\text { Triglycerides } \\
\text { (mmol/l) }\end{array}$ & $4.6(0.9)$ & $3.1(0.5)$ & 0.004 & $3.4(0.9)$ & 0.03 & 0.93 \\
\hline $\begin{array}{l}\text { Total food intake } \\
\text { (Kcal/day) }\end{array}$ & $1970(108.1)$ & $1880(159.4)$ & 0.03 & 1717 (112.8) & 0.03 & 0.69 \\
\hline $\begin{array}{c}\text { Aspartate } \\
\text { aminotransferase }\end{array}$ & $47.8(8.5)$ & $27.3(1.5)$ & 0.003 & $32.4(2.9)$ & 0.03 & 0.06 \\
\hline $\begin{array}{l}\text { Gamma glutamyl } \\
\text { transferase }\end{array}$ & $84.9(21.7)$ & $45.5(9.2)$ & 0.03 & $57.6(19.9)$ & 0.05 & 0.45 \\
\hline
\end{tabular}


Figure S2

Effect of metreleptin on insulin secretion in patients with $L M N A$ mutations
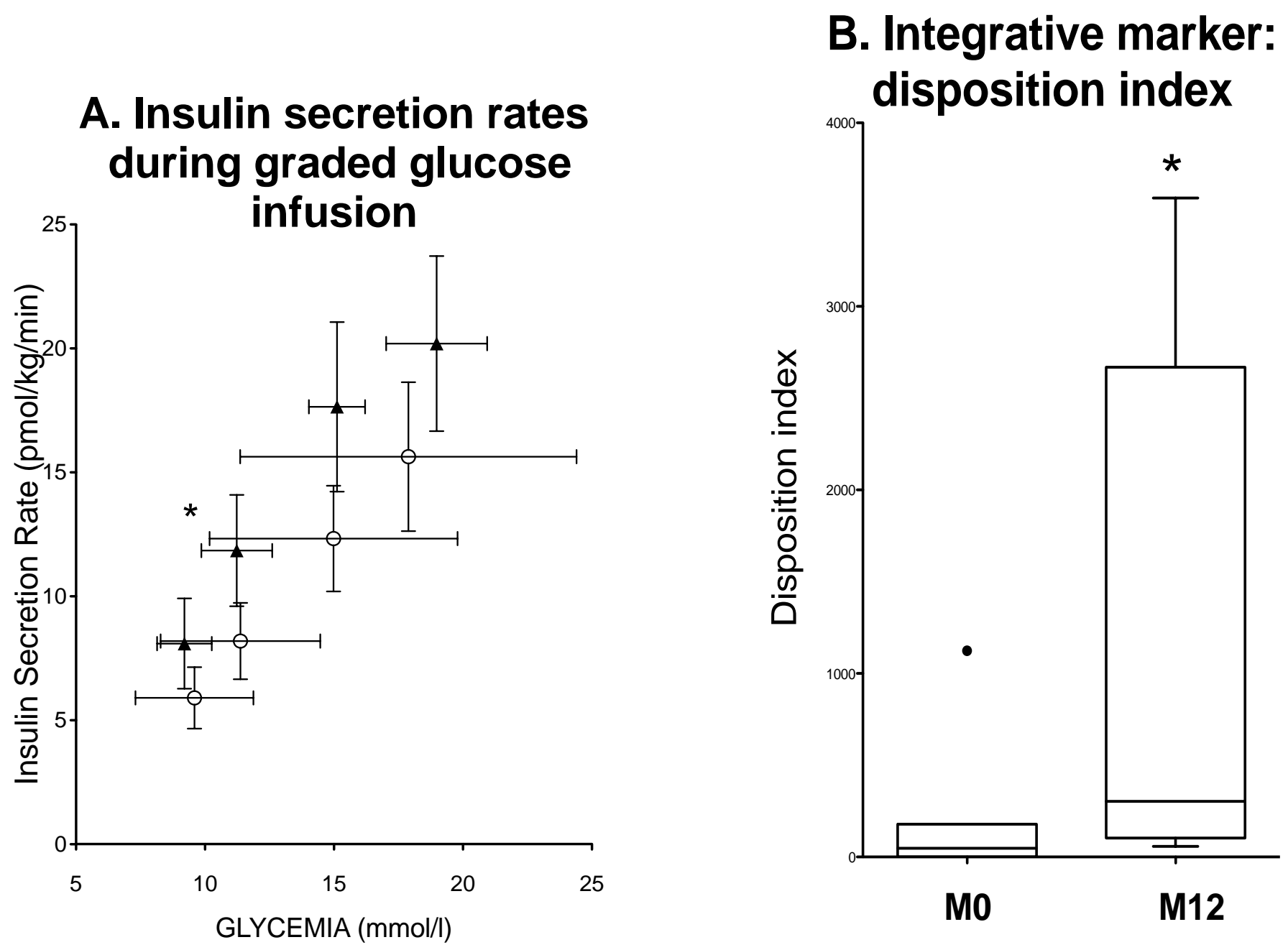

Baseline (M0)

A After one-year metreleptin therapy (M12) 
Table S3

Insulin secretion and insulin sensitivity indexes before and one year after metreleptin therapy

3 A. intravenous glucose tolerance test (IVGTT) followed by hyperglycemic clamps

\begin{tabular}{|c|c|c|c|c|c|c|c|}
\hline \multirow{2}{*}{ Patients } & \multirow{2}{*}{$\begin{array}{c}\text { Type of } \\
\text { lipodystrophy }\end{array}$} & \multicolumn{2}{|c|}{ Acute Insulin Response (pmol/kg/min) } & \multicolumn{2}{|c|}{$\begin{array}{c}\text { M-value/Insulinemia } \\
\text { (mg/kg of fat free mass/min/pmol/l) }\end{array}$} & \multicolumn{2}{|c|}{$\operatorname{AIR} \times \mathbf{M} / \mathbf{I}$} \\
\hline & & Mo & M12 & Mo & M12 & MO & M12 \\
\hline 1 & FPLD2 & 182.7 & 208 & 0.033 & 0.058 & 6.03 & 12.06 \\
\hline 2 & FPLD2 & 31.3 & 50 & 0.184 & 0.125 & 5.76 & 6.25 \\
\hline 3 & CGL1 & 80.1 & 532 & 0.035 & 0.061 & 2.80 & 32.45 \\
\hline 4 & CGL1 & 99 & 81.5 & 0.037 & 0.065 & 3.66 & 6.43 \\
\hline
\end{tabular}

3 B. Euglycemic hyperinsulinemic clamps and intravenous glucose tolerance test (IVGTT) followed by a glucose ramping

\begin{tabular}{|c|c|c|c|c|c|c|c|}
\hline \multirow{2}{*}{ Patients } & \multirow{2}{*}{$\begin{array}{c}\text { Type of } \\
\text { lipodystrophy }\end{array}$} & \multicolumn{2}{|c|}{ Acute Insulin Response (pmol/kg/min) } & \multicolumn{2}{|c|}{$\begin{array}{c}\text { M-value } \\
\text { (mg/kg of fat free mass/min) }\end{array}$} & \multicolumn{2}{|c|}{$\begin{array}{l}\text { Disposition index } \\
\text { (AIR x M-value) }\end{array}$} \\
\hline & & Mo & M12 & Mo & M12 & Mo & M12 \\
\hline 5 & CGL1 & 5 & 79.6 & 6.43 & 8.28 & 32.2 & 658.5 \\
\hline 6 & FPLD4 & 10 & 56.2 & 0 & 0.33 & 0 & 18.5 \\
\hline 7 & FPLD2 & 25.2 & 29.6 & 6.96 & 10.05 & 175.4 & 297.5 \\
\hline 8 & FPLD2 & 124.2 & 37.5 & 0 & 2.74 & 0 & 102.7 \\
\hline 9 & FPLD2 & 25.9 & 46.3 & 1.82 & 9.60 & 47.1 & 444.1 \\
\hline 10 & FPLD2 & 43 & 385.6 & 2.12 & 9.30 & 91.1 & 3586.0 \\
\hline 11 & $\begin{array}{l}\text { Progeroid } \\
\text { laminopathy }\end{array}$ & 426.4 & 27.8 & 0.05 & 2.05 & 21.8 & 57.0 \\
\hline 12 & FPLD2 & 155.8 & 222 & 7.21 & 12.03 & 1123.4 & 2670.7 \\
\hline 13 & FPLD3 & 9.7 & 15.7 & 0 & 0.77 & 0 & 12.1 \\
\hline 14 & CGL1 & 179.6 & 97 & 3.01 & 3.96 & 540.6 & 384.1 \\
\hline 15 & CGL1 & 24.2 & 44.1 & 3.02 & 3.96 & 73.1 & 174.6 \\
\hline 16 & $\begin{array}{l}\text { Mixed } \\
\text { laminopathy }\end{array}$ & 1.0 & 148 & 1.99 & 2.15 & 1.99 & 318.2 \\
\hline
\end{tabular}




\section{Supplementary Figure legends}

\section{Figure S1}

\section{Longitudinal effects of metreleptin therapy in the 16 patients}

Values of BMI (A), HbA1c (B) and serum triglycerides (C) are depicted as rectangles which represent $25^{\text {th }}$ and $75^{\text {th }}$ percentile values, with the median values depicted in-between. Whiskers represent the lowest datum still within 1.5 IQR of the lower quartile, and the highest datum still within 1.5 IQR of the upper quartile (Tukey boxplot). M: months after the onset of metreleptin therapy. *: $\mathrm{p}<0.05$ versus $\mathrm{M} 0$

Data expressed as mean (SEM) with statistical analyses are presented in (D).

\section{Figure S2}

\section{Effect of metreleptin on insulin secretion in patients with $L M N A$ mutations}

A. Insulin secretion rates (ISR) during graded glucose infusion were derived by deconvolution as described, for each of the four glucose infusion steps (of 4, 8, 10 and $12 \mathrm{mg}$ per $\mathrm{kg}$ of body weight of glucose per min), in 7 patients (patients 7 to 12 and patient 16). ISR expressed in pmol/kg of fat-free mass $/ \mathrm{min}$, were plotted against the corresponding mean glucose concentration. Mean values obtained at baseline are represented as empty circles, and those obtained at one year-metreleptin therapy as filled triangles. Whiskers represent SEM.

B. Disposition index, indicating the insulin secretion capacity relative to insulin sensitivity, was calculated in the same patients as the product of $\mathrm{M}$ value measured during the euglycemic hyperinsulinemic clamp by AIR. Rectangles represent $25^{\text {th }}$ and $75^{\text {th }}$ percentile values, with the median values depicted in-between. Whiskers represent the lowest datum still within 1.5 IQR of the lower quartile, and the highest datum still within 1.5 IQR of the upper quartile (Tukey boxplot).

M0: baseline, M12: after 12 months of metreleptin therapy; * $\mathrm{p}<0.05$ versus M0 